\title{
Selected issues in handwriting examination, graphology and their technology in document examination
}

\author{
RAFAŁ CIEŚLA \\ Department of Forensic Sciences \\ Faculty of Law, Administration and Economics \\ University of Wrocław, Poland \\ JOLANTA GRĘBOWIEC-BAFFONI \\ Faculty of Social Sciences \\ University of Wrocław, Poland \\ Alma Mater Studiorum Universita di Bologna \\ School of Law, Italy
}

In Italy expertise in graphology constitutes the basis for handwriting expert examination. In Poland handwriting examination is frequently equated with graphology ${ }^{1}$, both are interpreted as synonyms; therefore, forensic handwriting examination is popularly referred to as graphological examination ${ }^{2}$. However, most authors tend to adopt the view that they should be separated, maintaining that handwriting examination as a branch of forensic science concerned with forensic identification on the basis of handwriting distinctly differs from the theories identifying psychological features and personality traits of a person on the basis of his or her handwriting. Criticism of graphology emphasises the fact that

1 The term 'graphology' comes from Greek and means the science of writing (graphein — write and logos — science, word).

2 M. Goc, Współczesny model ekspertyzy pismoznawczej. Wykorzystanie nowych metod i technik badawczych, Warszawa 2015, p. 176 ff.

Nowa Kodyfikacja Prawa Karnego 45, 2017

(C) for this edition by CNS 
no research to date has provided scientific grounds for claiming any correspondence between psychophysical features of an individual and his or her handwriting ${ }^{3}$. On the other hand, it is true that to a certain degree psychological traits of a person are reflected in his or her handwriting, the latter being a systematic product of the combination of motoric skills and psychological potential. Handwriting, and a habitual way of executing it, is an integral part of a human being. Therefore, psychology admits that handwriting is sometimes useful in revealing certain aspects of a person's personality. However, psychological research does not identify handwriting's formal features, such as the shape of the letters, with permanent features of a person's intellect, character or temperament. At most, formal qualities of handwriting are recognised as properties of psychomotoric characteristics or symptoms of neurological disorders, some of which may cause considerable distortions of handwriting, manifesting themselves as a chaotic arrangement of the text, tremor or abrupt divergence of a handwriting stroke as seen, for example, in the handwriting of people suffering from Parkinson's or Alzheimer's disease ${ }^{4}$.

Italian graphology interprets handwriting as a product of individual and unique movements, which in itself enables identification of a person $^{5}$. Forensic science recognises the analysis of person's movements as a legitimate way of his or her identification, because contrary to an individual's physical appearance, which may be altered, the way of performing movements can not be changed. This principle is what graphology subscribes to as well, and thus it is not the appearance of characters that handwriting examination focuses on but the analysis of movements which produce a particular letter, word or signature.

Handwriting offers a possibility of examining personal movement recorded on the surface on which it is executed. No other movement process

${ }^{3}$ Z. Czeczot, T. Tomaszewski, Kryminalistyka ogólna, Toruń 1996, pp. 279-280; M. Goc, op. cit., p. 179.

${ }^{4}$ Ibid., p. 180.

5 G. Moretti, Trattato di Grafologia, Edizioni Messagero Padova, Padova 1985, p. 21; N. Palaferri, Indagine grafologica e il metodo morettiano, Edizioni Messagero Padova, Padova 2005, p. 32-33; J. Grębowiec-Baffoni, "Nierówność metodyczna w ekspertyzie pisma", [in:] Znaczenie aktualnych metod badań dokumentów w dowodzeniu sq̨owym, ed. Z. Kegel, R. Cieśla, Prawnicza i Ekonomiczna Biblioteka Cyfrowa, Uniwersytet Wrocławski, Wrocław 2012, pp. 117-142. 
is recorded so precisely while the material on which it is recorded enables profound analysis of its dynamics. Handwriting examination frequently involves examination of the surface itself (e.g. paper), its composition, physical and chemical properties as well as the composition of inks.

Paper has for ever been the most important material on which the human thought has been recorded. At present electronic carriers or virtual servers are used for the same purpose, but despite their producers' assurances, their actual reliability remains unknown ${ }^{6}$.

Paper ${ }^{7}$, or in fact a sheet of paper, is most frequently used for recording handwriting. Paper and inks (paints, etc.) interact. These chemical and physical interactions always depend on the type of ink and paper.

Due to its susceptibility to external factors and the potential for retaining distortions, paper records not only the shape and colour of the handwriting strokes, but also the relief resulting from the pressure of a writing implement. This property enables the assessment of the degree of pressure exerted by the writer, its potential abnormality and the sequence in which strokes were performed. These features are very important elements used in handwriting examination.

Observation of the properties of handwriting strokes is not possible with the naked eye and requires optical equipment, from a traditional magnifying glass and microscope to the most advanced optoelectronic

${ }^{6}$ D. Rams, D. Jarmińska, "Włókna papiernicze - historia i identyfikacja”, Notes Konserwatorski 2002, no. 2, p. 147.

${ }^{7}$ Paper (from $\pi$ á $u \rho \rho \varsigma$ (pápyros), lat. Carta papirea) — fibrous pulp of organic origin weighing from 28 to $200 \mathrm{~g} / \mathrm{m}^{2}$. Produced in the form of sheets or webs wound on rolls. After forming the mass on the mould, it is dehydrated, compacted, dried and smoothed in separate stages of continuous manufacturing process. Paper is usually produced from organic fibres: cellulose, wood pulp — obtained by grinding and milling pine logs (the so called pulpwood) in the process of mechanical defibering. When other plant fibres (straw, reed, cotton, flax, hemp, bamboo) are used, the process of chemical defibering is applied. Waste paper is also used previously subjected to a dispersion process. Apart from organic fibres, paper contains non-fibrous materials, such as potato starch and inorganic fillers kaolin, talc, gypsum, chalk, and sometimes hydrosulphite chemicals and dyes. Fillers improve paper properties (smoothness, opacity, whiteness, hue, etc). The type of fibres, fillers and their proportions depend on the standard, relative to the type and purpose of paper. Cf. PN-EN ISO 9706:2001. The origins and its production are tightly connected with the development of writing and culture. Throughout ages people recorded their thought with the use of various types of writing materials. 
equipment, such as a digital microscope, scanner or a photographic camera. Magnified images of samples are not only very helpful in comparing patterns of handwriting but they are also very important in producing visual material explaining expert's work and showing similarities and differences on the basis of which final conclusions were drawn. Therefore, both in Poland and Italy handwriting examination emphasises the importance of good quality macrophotographic material accompanied by the description of graphic dynamics, which facilitates an objective presentation of similarities and differences of handwriting patterns ${ }^{8}$. The visual material with the accompanying description enables a judge, prosecutor or any other party in judicial proceedings to comprehend fully the examination carried out by an expert and the final conclusions.

A handwriting expert must have specialist knowledge of neurophysiological process controlling the execution of handwriting and technical skills allowing him or her to produce magnified images of handwriting samples, thus ensuring objectivity of the examination whose results are admitted as evidence. This combination of expertise in the two fields is indispensable in handwriting examination.

\section{Properties of writing movement}

Identification potential of handwriting is confirmed by its individual character and uniqueness; there are no two identical handwriting styles, in the same way as there are no two identical people. Genetic research proves that despite many similarities even identical twins display certain differences. Similar conclusions were arrived at in handwriting examination ${ }^{9}$. Everyone differs in terms of their anatomy, however slightly, which is reflected in neurophysiological functioning.

${ }^{8}$ R. Cieśla, "Demonstrative materials as a component of expert appraisment" ["Dokumentacja poglądowa jako element składowy ekspertyz”], Jurisprudencija, Lietuvos Teises Universitas, Mokslo darbai 22(14), Vilnius 2001, pp. 35-40; R. Cieśla, F. Dellavalle, "Zastosowanie wybranych technik badawczych w celu ekstrakcji grafizmów z obrazów napieczętnych", [in:] Współczesna problematyka badań dokumentów, ed. R. Cieśla, Wrocław 2015, pp. 21-31.

9 Cf. Cz. Grzeszyk, E. Grzechnik, "Badania pisma ręcznego bliźniąt", [in:] Problemy z dowodu ekspertyzy dokumentów, ed. Z. Kegel, Drukarnia Uniwersytetu Wro- 
Each movement is controlled by the impulses originating in the brain and transmitted via the nervous system, and each of them always carries information about a person's neurophysiological condition and predispositions ${ }^{10}$.

Physiologists, neurophysiologists, psychologists and the researchers of sport are convinced about the influence of intellect and temperament on the type of movement. They maintain that it is affected by coordination skills and such psychophysical determinants as strength, endurance and muscular agility ${ }^{11}$. According to Blume, individual factors influencing movement are temperament, emotions, biopsychological constitution, experiences, illnesses and external factors, which together affect balance, rhythm, reactions, spatial imagination, diversity as well as combination of movements and their transformation ${ }^{12}$. Additionally, Pöhlman indicates planning and mental conceptions, sensory diversity, motoric control, observation of motoric coordination, motoric expression and anticipation ${ }^{13}$. Meinel and Schnabel also include here such factors as movement imagination, motoric flexibility and memory ${ }^{14}$. These individual and unique properties determine the type of movement characteristic of a given person.

cławskiego, Wrocław 2002, pp. 196-207; cf. Ch. Uhlig, "Podobieństwo pisma u bliźniąt jedno- i dwujajowych", [in] Problemy z dowodu ..., pp. 332-336.

10 J. Grębowiec-Baffoni, Piccolo manuale di grafologia morettiana. Il linguaggio non verbale della scrittura, Giochidimagia Editore, Cervia, 2016, pp. 10-11.

${ }^{11}$ H. Gundlah, Systembieziehungen körperlicher Fähigkeiten und Fertigkeiten. Theorie und Praxis der Körperkultur, 17 (Beiheft: Sozialismus und Körperkultur, Teil II), 1968, pp. 198-206 after P.L. Invernizzi, S. Dugnani, Didattica del movimento umano, vol. 1: Qualità utili per la salute, Carabà Universitaria, Milano 2014, p. 16.

12 D.D. Blume, Posizioni tecniche essenziali per lo sviluppo delle capacità coordinative, SdS, 1982.

13 R. Pöhlmann, Motorisches Lernen. Psychomotorische Grundlagen der Handlungsregulation sowie Lernprozeßgestaltung im Sport, Berlin 1985, after P. Bellotti, P. Delfini, Trent'anni di Scuola dello Sport, 1966-1996, Scuola\&Sport, Roma 1996, p. 59; G. Grassi, Teoria tecnica didattica dell'attività motoria ricreativa e del tempo libero, Le capacità coordinative, Corso di Laurea in Educazione Fisica e Tecnica Sportiva, Facoltà di Medicina e Chirurgia, Università degli Studi, di Pavia, Sede di Voghera, http:// www.0055.org/public/uni/orientamento.pdf.

14 K. Meinel, G. Schnabel, Teoria del Movimento, Società Stampa Sportiva, Roma 1984, p. 377.

Nowa Kodyfikacja Prawa Karnego 45, 2017

(C) for this edition by CNS 
Some claim that the movements of an energetic and resolute person are completely different from those of a weak and shy individual. Briskness or weakness is expressed by a unique way of combining movements, their diversity and balance, orientation, rhythm, reactions and the ability to adapt movement to current situations, which is especially important in various disciplines of sport.

The same aspects are equally important in achieving handwriting efficiency, which becomes automatic thanks to "training". Its analysis reveals individual characteristics enabling identification of a person.

Neurological factors affecting the type of handwriting strokes were studied by a German neurologist Rudolf Pophal, who in his extensive work "Handwriting and Brain. Graphology in View of the Stratigraphic Theory" 15 published in the 1940s analysed the degrees of handwriting tension resulting from the response of the muscles to the impulses sent from three centres in the brain which developed during the phylogenesis of humans: pale globe, striate body and cerebral cortex ${ }^{16}$. Alexander Luria's research on the role which various cerebral areas play in executing particular functions gave rise to the theory of three functional blocks of the brain, which confirmed the conclusions drawn by Pophal. Luria was particularly interested in the synthesis of particular neurological functions while writing by hand ${ }^{17}$. The issue of tension and relaxation of handwriting is continued by the Italian school of graphology, represented by, among others, Nazzareno Palaferri ${ }^{18}$ and Luciano Massi ${ }^{19}$, who compared Moretti's ${ }^{20}$ graph-

15 R. Pophal, Scrittura e cervello. La grafologia alla luce della teoria stratigrafica, EMP, Padova 1990.

16 Some aspects of Pophal's work were discussed in J. Grębowiec-Baffoni, "Neurofizjologia w geście graficznym", [in:] Wplyw badań eksperymentalnych na wartość dowodowa ekspertyzy dokumentów, ed. Z. Kegel, Beta-druk, Wrocław 2008, pp. 167-188.

${ }_{17}$ A. Luria, Neuropsicologia del linguaggio grafico, EMP, Padova 1984 (Translated by U. Marazzi).

${ }^{18}$ Cf. N. Palaferri, L'indagine grafologica e il metodo morettiano, EMP, Padova 2005.

${ }^{19}$ L. Massi, Tensione e Grafologia. Pophal e Moretti a confronto, Youcanprint 2013.

${ }^{20}$ Girolamo Moretti was convinced that movement should be seen as a psychophysiological product because it originates in the brain as a result of psychophysiological processes and as such it is expressed outwardly. For this reason examination of handwriting becomes the analysis of human psychophysiological entity, expressed in the movement as its strength, flexibility, methodical and non-methodical inequality, briskness, 
ological method with the neurological and psychological research carried out by Pophal and Luria in terms of the development of handwriting.

Unusual handwriting patterns, rate of change in muscle work concurrently maintaining the same tension in performing consecutive strokes, movement within graphic space with the use of various degrees of pressure, varying ease of executing curves and angles are only a few of the features which may be helpful in identification of the writer. In order to examine these elements a handwriting expert must have the knowledge of psychophysical dynamics and responses of muscle groups responsible for executing individual movements. Knowledge of the dynamics enables the identification of natural and personal elements which result from psychophysiological processes and separating them from unnatural elements of the handwriting.

Handwriting is the most complicated human activity, not only because it requires very good skills of manipulation and precise movement but also because it involves a great number of cerebral centres, the peripheral nervous system and neurophysiological processes. Sight, speech, hearing, skeletal and muscular systems work together to produce a character, setting off a whole chain of processes: perception, visual and physical coordination, attention, concentration, linguistic and symbolic association, linguistic and physical planning (more or less conscious) accompanied by the reception of tactile stimuli indispensable for visual and tactile coordination responsible for appropriate gripping of a writing implement and moving it, exerting appropriate pressure, while the above-mentioned processes involved in writing communicate, exchanging information.

When movements become automated, writing by hand is immediate and involuntary, involving individual groups of muscles working alternatively. Muscles contract and relax and exactly this factor constitutes one of the principles of graphological examination. Repeatable movements become automated, even those performing very difficult functions, requiring very quick alternation of the involved muscle

spontaneity and in symbolic processes accompanying the movement. The analysis of movement originating from mental and neurophysiologial processes enables determining some mental and physical features of a person. Moretti, the founder of the Italian school of graphology and the author of over forty publications, is one of the most respected graphology experts in the world. 
groups and sudden alterations of contraction and relaxation of muscles. Unusual and difficult graphic patterns observed by an expert become a very important point of reference for the comparisons made during the examination.

\section{Recording movement}

Recording movement is today possible thanks to advanced technology. Modern equipment enables the playback of the recorded movement at any speed and its analysis, yet the images are often transitory in nature, because film frames fade while the analysis of movement requires continuous playback.

Contrary to the above, the image of the movement recorded on paper is durable and easily accessible. Complexity of graphic movement enables detailed analysis of its various aspects, such as dynamics, pace, rate of slowing down, linking, spatial arrangement, pressure and many other, even though a small size of graphic patterns requires the use of appropriate equipment magnifying the picture in order to analyse every feature of the movement creating them. Modern technology is very helpful here and a traditional magnifying glass and optical microscope are increasingly more frequently replaced (often too hastily) by scanners, digital microscopes and cameras, which enable direct observation of magnified recorded images.

Due to the ease with which the scanner records and magnifies images, it is very commonly used in handwriting examination, even though it is not always able to render the dynamics of how graphic patterns were formed, especially when the strokes executed in the same colour cross. Unfortunately, the latter aspect is very important when examining the instances of new handwriting added to the original one, determining the sequence in which handwriting originating from two sources, e.g. written by two people, was executed or analysing print combined with handwriting. The scanner also fails to show the depth of the groove produced by a stroke, especially when the handwriting was executed with strong, uniform pressure and the absence of shading prevents any conclusions as to the variability of the energy applied in different fragments of the examined sample. 
It is worth noting here that despite its seeming two-dimensionality, the characters written on paper are in fact three-dimensional, i.e. apart from height and width there is also depth resulting from the pressure of the writing implement; therefore, it is important that an original sample of handwriting may be analysed with the use of a traditional magnifying glass or microscope.

Limitations in the use of the scanner result from the fact that it produces two-dimensional images, which do not render convexities and concavities of handwriting strokes, important in the analysis of the applied pressure and the sequence in which they cross. However, it may be used successfully in the case of handwriting samples characterised by good shading and different colours of inks of the crossing strokes, even though a digital microscope or camera produce more detailed images. Both also produce two-dimensional pictures but the distance between an analysed sample and the device as well as appropriate lighting render the perspective of convexities and concavities. Additionally, in the case of samples produced with different inks (e.g. black printer's ink and black ballpoint ink) the magnification enables distinguishing the differences in the compositions of particles of the used inks and the bonding between them, which in turn enables distinguishing between the samples ${ }^{21}$.

The reproductions presented below illustrate the differences between the images of handwriting samples produced by a scanner and a camera with lateral lighting (Fig. 1 and 2).

In the image from the scanner the difference in pressure between the stem of letter ' $t$ ' and the stroke crossing it is practically invisible while in the image from the camera the difference is clearly perceptible. The stroke crossing letter ' $t$ ' was formed with greater pressure (see the arrows). Similar features are seen in the stroke preceding the letter. The pressure changes towards the top, which is more perceptible in the image from the camera (see the sections marked with dotted arrows).

As follows from the above, both in Italy and in Poland the knowledge of techniques of acquiring images of handwriting samples with the use of microscope or camera as well as the use of appropriate lighting is as im-

${ }^{21}$ Cf. R. Cieśla, F. Dellavalle, "Zastosowanie wybranych technik badawczych w celu ekstrakcji grafizmów z obrazów napieczętnych”, [in:] Wspótczesna problematyka badań dokumentów, ed. R. Cieśla, Uniwersytet Wrocławski, Wrocław 2015, pp. 21-31. 



Figure 1 and 2. The images of the same handwriting sample produced by a scanner (Fig. 1) and a camera (Fig. 2). The differences in the width of the strokes are visible in the images produced by both appliances; yet, the diversity of pressure in forming the stroke is better visible in the image produced by a camera with lateral lighting.

portant for a graphologist/handwriting expert as the knowledge of neurophysiological processes involved in handwriting. Without good-quality images reliable examination and an objective expert opinion are practically impossible 22 .

\section{On the essence of knowledge of graphic movement processes and selection of appropriate optical techniques in handwriting examination}

The case of handwriting examination discussed below is an example of complex competences of a graphologist/handwriting expert, where both the knowledge of neurophysiology and the use of appropriate optical equipment proved essential.

The case is concerned with a private contract concluded between Silvio F. and his ex-wife. The contract was allegedly initialled by Silvio F., who denied it, claiming that the initials were forged. The examination consisted in comparing the questioned initials with 270 comparison

22 It is worth noting that a graphologist/handwriting expert must know how to acquire information from the chemical and physical examination of handwriting. Because a document - evidence in the proceedings — is partly damaged during the examination, in each case it requires court's or prosecutor's consent. Today such examination is being replaced by modern equipment processing data in $3 \mathrm{D}$ available in specialist laboratories.

Nowa Kodyfikacja Prawa Karnego 45, 2017

(C) for this edition by CNS 
signatures collected from various documents signed by Silvio F. and the samples which he wrote as requested by the court. For technical reasons the questioned initials were marked $\mathrm{X}$ and all the comparison samples as A with consecutive numbers from 1 to 270 .

Preliminary examination with the use of a magnifying glass already caused doubts as to the authenticity of the initials due to the unnatural direction of the stroke, primarily its middle part, characterised by initial rigidity of movement and uneven pressure (due to irregular muscle tension). None of the 270 comparison signatures displayed similar dynamics.

However, possibly adverse external conditions (e.g. uncomfortable position when signing) or such external factors as illness or excessive emotional state resulting in an atypical form of the initials had to be taken into consideration, especially that in the remaining parts of the initials strokes were smooth and congruous with the elements observed in the comparison signatures.

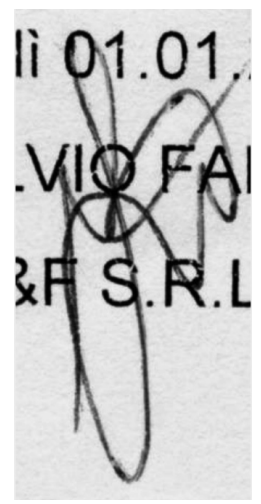

Questioned signature marked as X

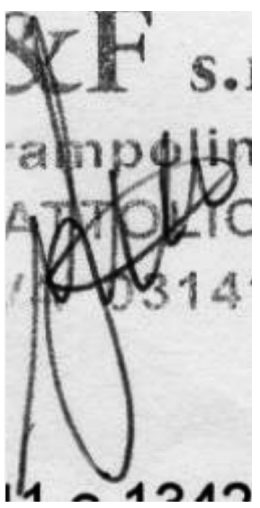

Comparison signature marked as A1

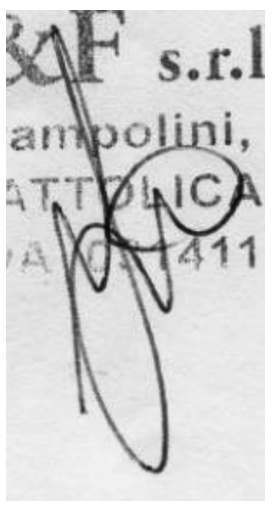

Comparison signature marked as A2

Figure 3. Scans of the questioned and comparison signatures, provided by the plaintiff with the motion to initiate proceedings.

More detailed examination of comparison samples revealed a section difficult to execute, which might prove useful for comparative purposes. It was a briskly made initial stroke visible as a rigid long line running from bottom to top, sloping downwards abruptly with a gentle curve 


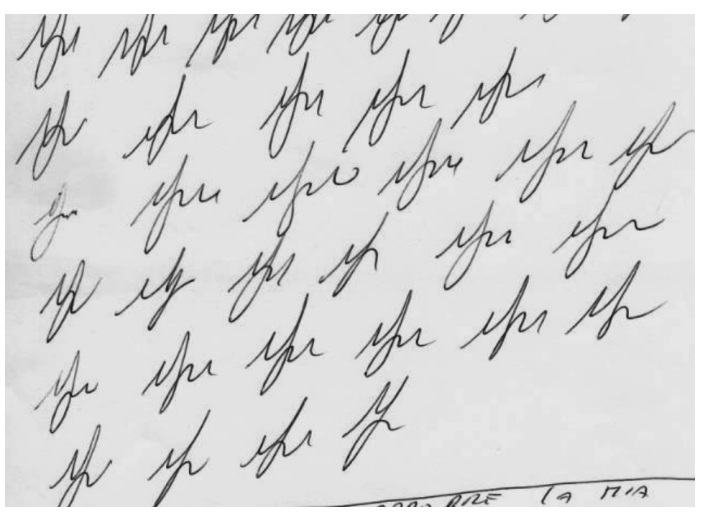

Figure 4. Fragment of comparison material acquired from Silvio F.

only to become rigid and turn abruptly upwards again. Its complexity consisted in the fact that quite strong and not very diversified pressure (present in the whole initials) required continuous and alternating, very quick contraction and relaxation of abductor and adductor muscles of the wrist and fingers. After the stroke gained speed, it curved abruptly, displaying flexibility and rounding of movement despite low diversity of pressure. In this context the beginning of the process of writing the initials was a difficult graphical undertaking, highly automated, which became an essential point of reference, constituting an important element in the comparative examination (Fig. 5).

Because the movement in this fragment of the initials was difficult and unusual, a potential forger might have had problems executing it, which, however, was difficult to prove examining the signature with a magnifying glass.

Even though preliminary examination of the questioned initials prompted doubts as to their authenticity (revealing uncertain and quite atypical movement of the stroke in its middle part mentioned above), examination of the stroke initiating the initials failed to determine a precise degree of briskness and rigidity of the movement because it crossed another stroke forming the initials.

Examination of that section of the questioned signature might have provided a definite answer as to the authenticity of the initials. However, an additional difficulty consisted in the fact that the initials were executed 

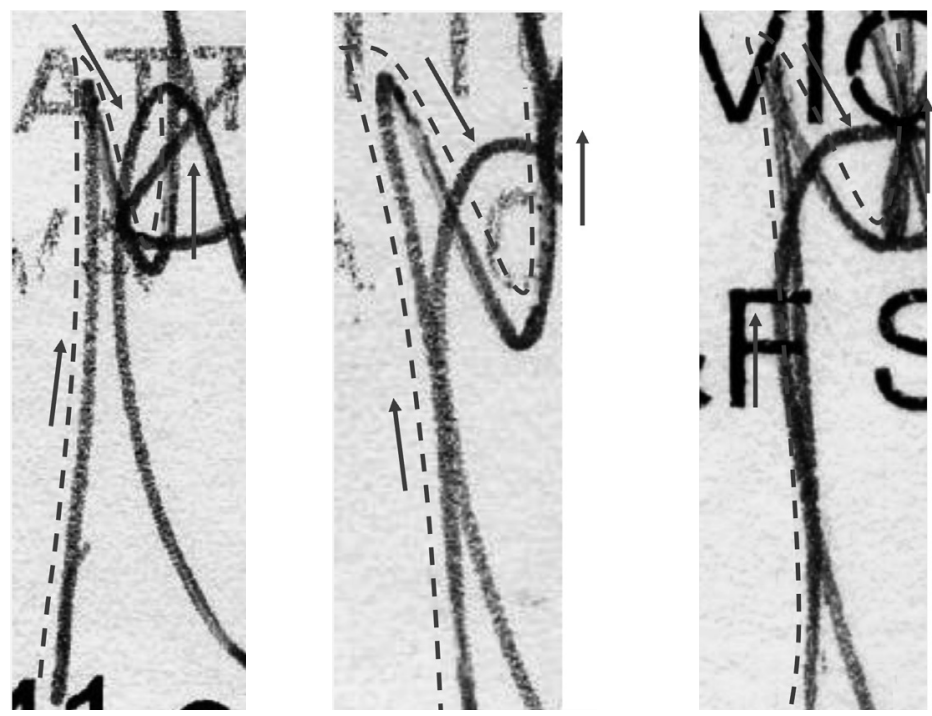

Figure 5. Comparative signatures A7 and A8 and the questioned signature display similar dynamics of executing angles and abrupt curves initiating the initials, which would be difficult to imitate in quick and brisk handwriting.

in black ink, which in a few places ran across printed text containing Silvio F.'s personal data.

Additionally, general dynamics of the signature required a high degree of automating the movement because despite low diversity of pressure accompanied by a great degree of alteration of tension and flexibility, Silvio F. had no difficulties in maintaining the continuity of the stroke, both in the initials and signatures. However, such difficulties may have been encountered by a forger, which might be revealed when the picture was magnified.

For this purpose the questioned initials were scanned, but even when the picture was magnified, it was difficult to distinguish between the black lines written with a ballpen overlapping the black text printed on the document. Examination of the initial stroke and the strokes following it magnified by the scanner might have been decisive as to their authenticity, but it turned out that even the magnified picture failed to produce conclusive evidence. A vague outline was observed at the point where the line curved, but neither its exact shape nor origin could be determined (Fig. 6). 
After unsuccessful examination of the picture produced by the scanner, the questioned initials were analysed with the use of a digital microscope, revealing distinct differences in the composition of the black printer's ink and the black ballpoint ink. This showed that the initials' first part was not written with one stroke, which — seen under the magnifying glass and on the magnified scan - looked as vague shading. Only the use of a digital microscope proved that executing the initial fragment of the initials, which required considerably automated movement, was actually made in two attempts, overlapping the black print (Fig. 7).

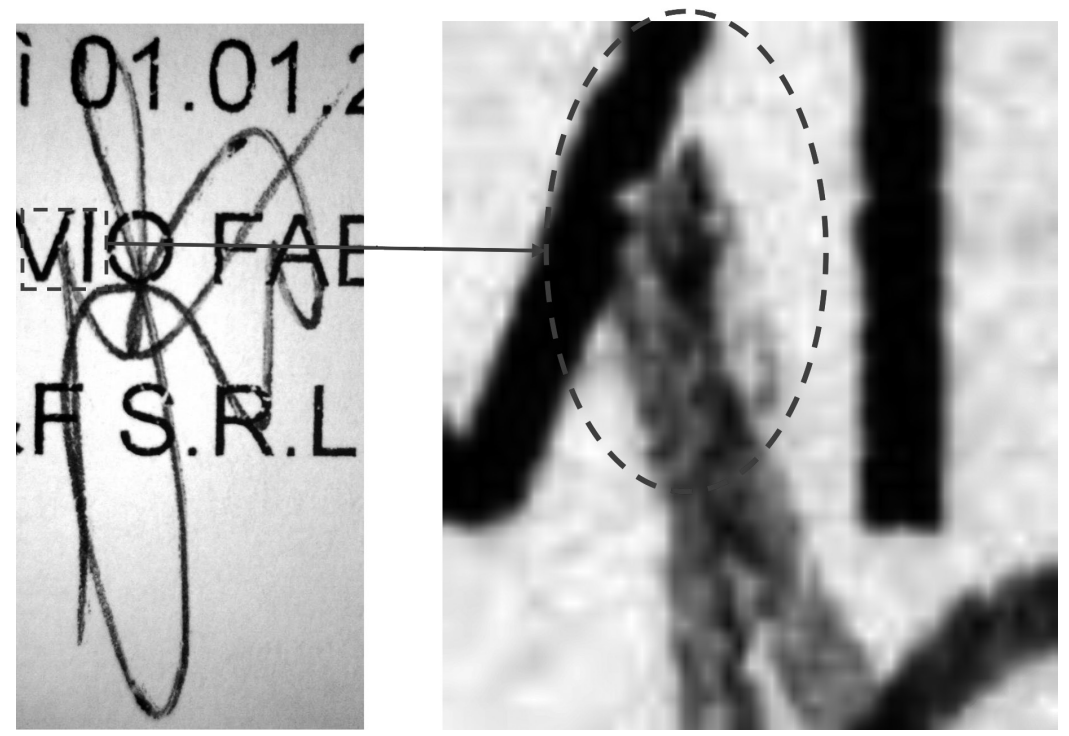

Figure 6. Magnified scan of the section difficult to execute reveals a vague outline of an unknown origin

Further magnification revealed a point of discontinuation of the stroke, which was ultimately executed in two attempts (Fig. 8).

Further examination revealed abnormal changes in pressure absent in comparison signatures as well as traces of tremor impossible in automated handwriting, which conclusively proved that the questioned initials were not written by Silvio F.

During the further stages of examination of the questioned initials yet another point was observed, which the scanner showed as shapeless shad- 

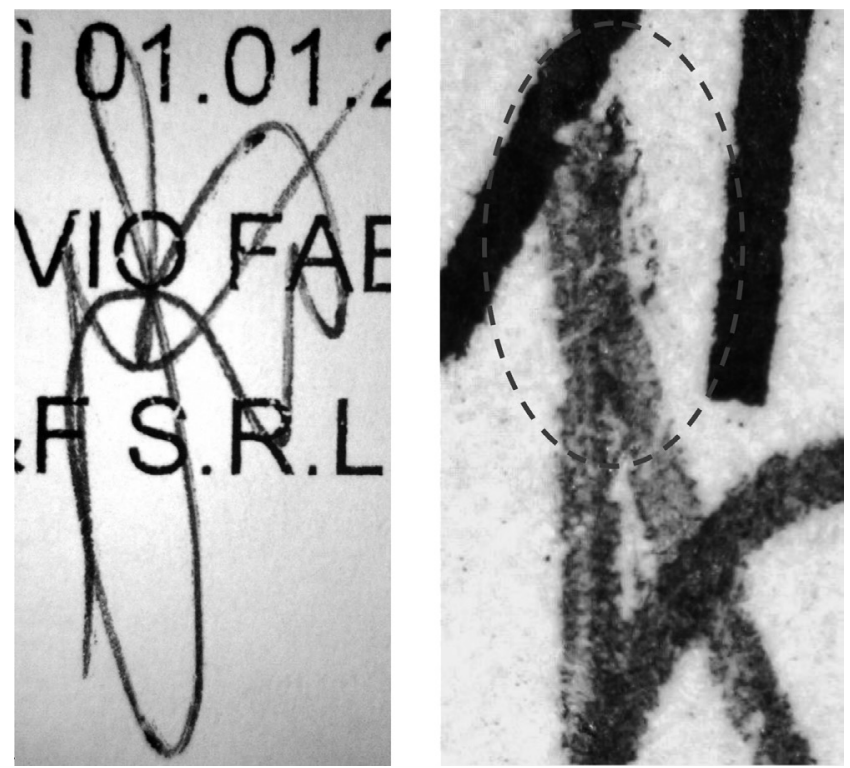

Figure 7. Questioned initials X. On the left is the scan of the signature, on the right a photograph of the same fragment taken with the digital microscope. Examination under the microscope revealed a thin stroke going outside the path of the main stroke and separating from it. At the point marked with the arrow the angle difficult to imitate was made in two attempts. Magnification showed presence of traces of ink distributed outside the path of the main stroke

ing, difficult to define because it overlapped the printed text. Examination under the microscope revealed that one stroke was discontinued and the other one began at the point of contact with the printed figure " 0 " (Fig. 9).

This example proves not only that it is necessary to be familiar with neurophysiological dynamics, which enables determining individual and unique movement, but also that precise and conclusive handwriting examination requires the use of advanced optical technology of recording images. Such equipment enables preparation of adequate photographic material, which facilitates understanding the procedure of examination and the resulting conclusions. Magnified images of the examined signatures and their fragments illustrate the elements escaping easy verbal description due to the complex nature of graphic traces and composition of paper and inks. 

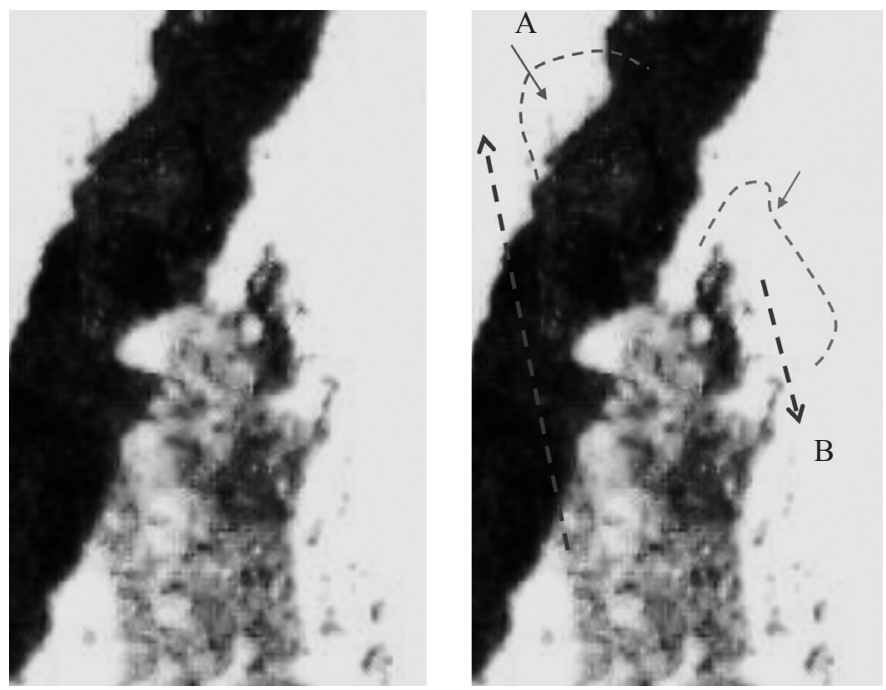

Figure 8. Photograph taken with the digital microscope; on the right the same photograph with arrows marking the place where one stroke was discontinued and a new one began. The arrows indicate the direction of movement. A - Spots of ink in the stroke path blurring due to slowing down of the movement forming the first stroke of the initials; $\mathrm{B}$ - Beginning of the new stroke.

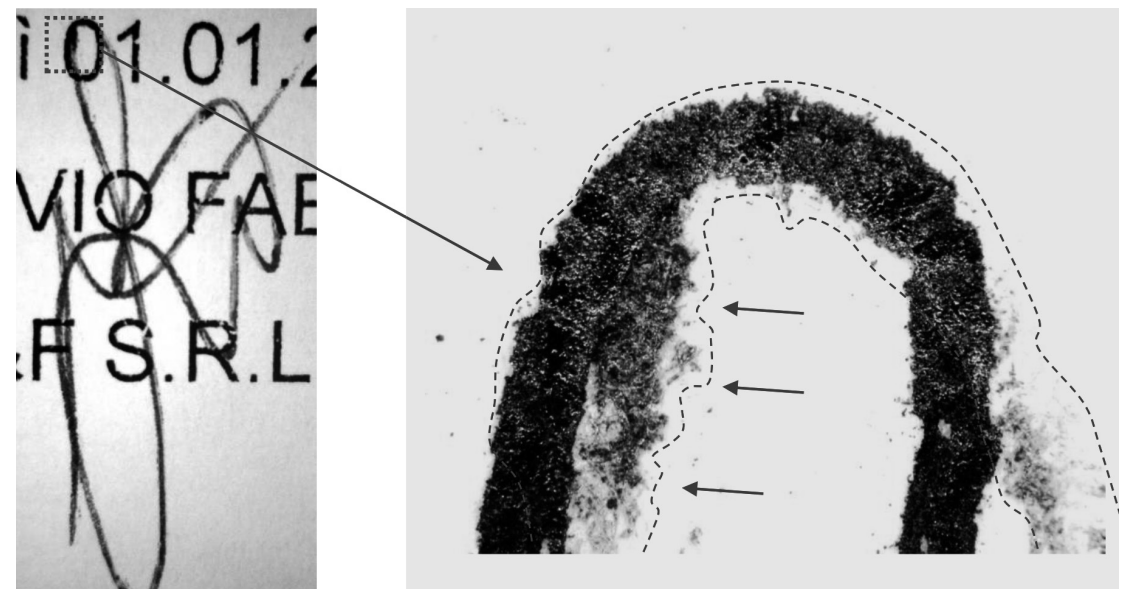

Figure 9. Distinct thickening of the stroke executed in ballpoint ink at the point where figure ' 0 ' is printed. The 'jagged' path (marked with arrows) reveals uncertain, non-uniform and slowing down movement. 


\section{References}

Bellotti P., Delfini P., Trent'anni di Scuola dello Sport, 1966-1996, Scuola\&Sport, Roma 1996. Blume D.D., Posizioni tecniche essenziali per lo sviluppo delle capacità coordinative, SdS, 1982.

Cieśla R., "Demonstrative Materials as a Component of Expert Appraisment" ["Dokumentacja poglądowa jako element składowy ekspertyz"], Jurisprudencija, Lietuvos Teises Universitas, Mokslo darbai, 22(14), Vilnius 2001, pp. 35-40.

Cieśla R., Dellavalle F., "Zastosowanie wybranych technik badawczych w celu ekstrakcji grafizmów z obrazów napieczętnych”, [in:] R. Cieśla (ed.), Współczesna problematyka badań dokumentów, Wrocław 2015, pp. 21-31.

Czeczot Z., Tomaszewski T., Kryminalistyka ogólna, Toruń 1996, pp. 279-280.

Goc M., Współczesny model ekspertyzy pismoznawczej. Wykorzystanie nowych metod i technik badawczych, Warszawa 2015, p. $176 \mathrm{ff}$.

Grassi G., Teoria tecnica didattica dell'attività motoria ricreativa e del tempo libero, Le capacità coordinative, Corso di Laurea in Educazione Fisica e Tecnica Sportiva, Facoltà di Medicina e Chirurgia, Università degli Studi, di Pavia, Sede di Voghera, http:// www.0055.org/public/uni/orientamento.pdf.

Grębowiec-Baffoni J., "Neurofizjologia w geście graficznym”, [in:] Z. Kegel (ed.) Wptyw badań eksperymentalnych na wartość dowodową ekspertyzy dokumentów, Beta-druk, Wrocław 2008, pp. 167-188.

Grębowiec-Baffoni J., "Nierówność metodyczna w ekspertyzie pisma", [in:] Z. Kegel, R. Cieśla (eds.) Znaczenie aktualnych metod badań dokumentów $w$ dowodzeniu sąowym, Prawnicza i Ekonomiczna Biblioteka Cyfrowa, Katedra Kryminalistyki Wydziału Prawa, Administracji i Ekonomii, Uniwersytet Wrocławski, Wrocław 2012, pp. 117-142.

Grębowiec-Baffoni J., Piccolo manuale di grafologia morettiana. Il linguaggio non verbale della scrittura, Giochidimagia Editore, Cervia, 2016, pp. 10-11.

Grzeszyk C., Grzechnik E., "Badania pisma ręcznego bliźniąt”, [in:] R. Cieśla (ed.), Współczesna problematyka badań dokumentów, Drukarnia Uniwersytetu Wrocławskiego, Wrocław 2015, pp. 196-207.

Gundlah H., Systembieziehungen körperlicher Fähigkeiten und Fertigkeiten. Theorie und Praxis der Körperkultur, 17 (Beiheft: Sozialismus und Körperkultur, Teil II), 1968, pp. 198-206.

Invernizzi P.L., Dugnani S., Didattica del movimento umano, vol.1: Qualità utili per la salute, Carabà Universitaria, Milano 2014, p. 16.

Łuria A., Neuropsicologia del linguaggio grafico, EMP, Padova 1984 (translated by U. Marazzi).

Massi L., Tensione e Grafologia. Pophal e Moretti a confronto, Youcanprint 2013.

Meinel K., Schnabel G., Teoria del Movimento, Società Stampa Sportiva, Roma 1984, p. 377.

Moretti G., Trattato di Grafologia, Edizioni Messagero Padova, Padova 1985, p. 21.

Palaferri N., Indagine grafologica e il metodo morettiano, Edizioni Messagero Padova, Padova 2005.

Nowa Kodyfikacja Prawa Karnego 45, 2017

(C) for this edition by CNS 
Palaferri N., L'indagine grafologica e il metodo morettiano, EMP, Padova 2005, pp. 32-33.

Pophal R. Scrittura e cervello. La grafologia alla luce della teoria stratigrafica, EMP, Padova 1990.

Pöhlmann R., Motorisches Lernen. Psychomotorische Grundlagen der Handlungsregulation sowie Lernprozeßgestaltung im Sport, Berlin 1985, p. 59.

Rams D., Jarmińska D., "Włókna papiernicze — historia i identyfikacja”, Notes Konserwatorski 2, 2002, p. 147.

Uhlig Ch., "Podobieństwo pisma u bliźniąt jedno- i dwujajowych", [in:] Z. Kegel (ed.), Problemy z dowodu ekspertyzy dokumentów, Drukarnia Uniwersytetu Wrocławskiego, Wrocław 2002, pp. 332-336.

\section{Summary}

This article aims at introducing the complex nature of handwriting examination for judicial purposes and the resulting competences which a handwriting expert must have. The knowledge of neurophysiological conditioning of handwriting strokes, together with the knowledge of inks, their physical and chemical reactions with surfaces on which handwriting is applied, techniques allowing their observation and acquiring clear enlarged photographic images are indispensable for a correct expert examination, explanation of how the conclusions were arrived at and illustrating the results. Appropriate selection of techniques of acquiring images requires not only the knowledge of optical and lighting equipment but also practical skills in its appropriate use. Thus, handwriting examination combines the knowledge from various areas: neurophysiology of movement, psychology of handwriting, chemistry, physics and use of optical equipment, which together guarantee objective and reliable examination yielding correct results.

Keywords: document, handwriting examination, judicial graphology, technical examination of documents, expert examination, forgery, signature, expert. 